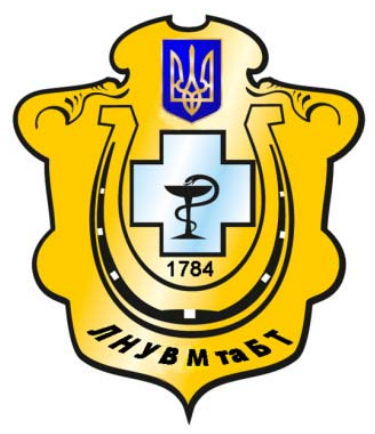

Науковий вісник Львівського національного університету ветеринарної медицини та біотехнологій імені С.3. Гжицького

Scientific Messenger of Lviv National University of Veterinary Medicine and Biotechnologies named after S.Z. Gzhytskyj

doi:10.15421/nvlvet7324

ISSN 2518-7554 print

ISSN 2518-1327 online

http://nvlvet.com.ua/

УДК 636.1.088 : 612.11/.12

\title{
Гематологічні та біохімічні показники крові спортивних коней української верхової та тракененської порід
}

\author{
М.В. Чорнийํㅜ О.С. Мачула ${ }^{1}$, А.О. Крилова ${ }^{1}$, П.П. Антоненко ${ }^{2}$, В.В. Вороняк ${ }^{3}$ \\ dmchorn@ukr.net \\ ${ }^{1}$ Харківська державна зооветеринарна академія, \\ смт Мала Данилівка, Дергачівський р-н, Харківська обл., 62341, Україна; \\ ${ }^{2}$ Дніпропетровський державний аграрно-економічний університет, \\ вул. Ворочилова, 25, м. Дніпро, 49600, Україна; \\ $3^{3}$ Львівський національний університет ветеринарної медицини та біотехнологій імені С. 3. Гжицького, \\ вул. Пекарська, 50, м. Львів, 79010, Украӥна
}

В статті наведені результати досліджень морфологічного складу і біохімічних показників крові спортивних коней украйнської верхової та тракененської пород. Метою роботи було вивчення фізичних навантажень на гематологічні показники, за якими можно судити про рівень тринованості і відповідно виконаних навантажень на клініко-фізологічний стан коней. В завдання досліджень входило встановлення впливу тренувань (до і після) на морфологічний склад крові, з'ясування змін біохімічного складу сироватки (глюкози, резервної лужності і молочної кислоти) у коней вказаних порід 4-6 річного віку. Коні утримувалися в однакових умовах мікроклімату, годування і обслуговування. Оиінку клінічного стану тварин проводили за складом лейкоцитарної формули: кількості еритроцитів, лейкоцитів, лімфоцитів, моноцитів, нейтрофілів, тромбоцитів, а також вмісту гемоглобіну, біохімічні показники - за загальноприйнятими у ветеринарії методами.

Результати досліджень показали, щуо після інтенсивних тренувань у коней УВП підвищується концентрація гемоглобіну на - 12,5\%, у тракенів - на 3,8\% (P < 0,05), чим викликана відповідна реакиія організму на гіпоксію, обумовленою меншою адаптаиією до стресових впливів. Це підтверджується збільшенням після навантажень кількості еритроцитів на 13,1\%, нейтрофілів на - 3,3\%, лімфоцитів на - 7,8\%, (P<0,05). Рівень глюкози, забезпечує на 55\% енергетичну потребу організму, у тварин тракененської породи після навантажень знизився на 4,5\%, у УВП на 17,2\% $(P<0,05)$, що свідчить про відсутність негативних впливів на фізіологічний стан коней.

Ключові слова: українська верхова порода, тракененська порода, морфологічний склад крові, глюкоза, молочна кислота, кислотна ємність крові.

\section{Гематологические и биохимические показатели крови спортивных лошадей украинской верховой и тракенской пород}

\author{
Н.В. Черный ${ }^{1}$, О.С. Мачула ${ }^{1}$, А.О. Крылова ${ }^{1}$, П.П. Антоненко ${ }^{2}$, В.В. Вороняк ${ }^{3}$ \\ dmchorn@ukr.net \\ ${ }^{1}$ Харьковская государственная зооветеринарная академия, \\ пгт Малая Даниловка, Дергачёвский р-н, Харьковская обл., 62341, Украина; \\ ${ }^{2}$ Днепропетровский государственный аграрно-экономический университет, \\ ул. Ворочилова, 25, г. Днепр, 49600, Украина; \\ 3 Львовский национальный университет ветеринарной медищины и биотехнологий имени С.3. Гжицкого, \\ ул. Пекарская, 50, г. Львов, 79010, Украина
}

Citation:

Chernyi, N.V., Machula, O.S., Krylova, A.O., Antonenko, P.P., Voronyak, V.V. (2017). Hematological and biochemical parameters of the blood sports horses of ukrainian riding and trakenskoye breeds. Scientific Messenger LNUVMBT named after S.Z. Gzhytskyj, 19(73), 118-121. 
В статье приведены результаты исследований морфологического состава и биохимических показателей крови спортивных лошадей украинской верховой и тракененской породы. Целью работы было изучение физических нагрузок на гематологические показатели, по которым можно судить об уровне тренированости и соответственно выполненных нагрузок на клинико-физологическое состояние лошадей. В задачу исследований входило установление влияния тренировок (до и после) на морфологический состав крови, выяснения изменений биохимического состава сыворотки (глюкозы, резервной иелочности и молочной кислоты) у лошадей указанных пород 4-6 летнего возраста. Кони содержались в одинаковых условиях микроклимата, кормления и обслуживания. Оиенку клинического состояния животных проводили по составу лейкоцитарной формуль: количества эритроцитов, лейкочитов, лимфоцитов, моночитов, нейтрофилов, тромбоцитов, а также содержания гемоглобина, биохимическим показателям по общепринятым в ветеринарии методами.

Результаты исследований показали, что после интенсивных тренировок у лошадей УВП повышается концентрация гемоглобина на - 12,5\%, у тракенов - на 3,8\% (P < 0,05), чем вызвана ответная реакиия организма на гипоксию, обусловленной меньшей адаптацией к стрессовым воздействиям. Это подтверждается увеличением после нагрузок количества эритроцитов на - 13,1\%, нейтрофилов на - 3,3\%, лимфоцитов на - 7,8\% (P<0,05). Уровень глюкозы, обеспечивает на 55\% энергетической потребности организма, у животных тракененской породы после нагрузок снизился на 4,5\%, в УВП на $17,2 \%$ (P < 0,05), что свидетельствует отсутствием негативных воздействий на физиологическое состояние лошадей.

Ключевые слова: украинская верховая порода, тракененская порода, морфологический состав крови, глюкоза, молочная кислота, кислотная емкость крови.

\title{
Hematological and biochemical parameters of the blood sports horses of ukrainian riding and trakenskoye breeds
}

\author{
N.V. Chernyi ${ }^{1}$, O.S. Machula ${ }^{1}$, A.O. Krylova ${ }^{1}$, P.P. Antonenko ${ }^{2}$, V.V.Voronyak ${ }^{3}$ \\ dmchorn@ukr.net \\ ${ }^{I}$ Kharkov State Zooveterinary Academy, \\ Mala Danylivka, Kharkiv region, Dergachi district, 62341, Ukraine; \\ ${ }^{2}$ Dnipropetrovsk state agrarian-economic university, \\ Voroshilov Str., 25, Dnepr, 49600, Ukraine; \\ ${ }^{3}$ Lviv national university of veterinary medicine and biotechnologies named after S. Gzhytskyj, \\ Pekarska Str., 50, Lviv, 79010, Ukraine
}

The article presents the results of studies of the morphological composition and biochemical indices of the blood of sports horses of the Ukrainian riding and trakehner breed. The aim of the work was to study the physical loads on the hematologic indices, by which it is possible to judge the level of training and, accordingly, the loads performed on the clinical and physiological condition of horses. The research task consisted of determining the effect of training (before and after) on the morphological composition of the blood, clarifying the changes in the biochemical composition of the serum (glucose, reserve alkalinity and lactic acid) in horses of these breeds of 6 years of age. The horses were kept in the same conditions of microclimate, feeding and maintenance. Evaluation of the clinical state of animals was carried out according to the composition of the leukocyte formula: the number of erythrocytes, leukocytes, lymphocytes, monocytes, neutrophils, platelets and hemoglobin content, and biochemical parameters according to methods of research common in veterinary medicine.

The results of the studies showed that after intensive training in horses, the level of hemoglobin increases by - 12.5\%, in traken by 3.8\% (P<0.05), what causes the response of the body to hypoxia, due to less adaptation to stressful Impacts. This is confirmed by an increase in the number of red blood cells after loading - 13.1\%, neutrophils by 3.3\%, lymphocytes by $7.8 \%(P<0.05)$. The level of glucose provides $55 \%$ of the energy requirement of the body, in the case of the trakehner breed, after the load, it decreased by $4.5 \%$, in the OHR by $17.2 \%(P<0.05)$, which indicates the absence of negative effects on the physiological condition of the horses. blood.

Key words: ukrainian riding breed, trakehen breed, morphological composition of blood, glucose, lactic acid, acid capacity of

\section{Вступ}

Нормальна життєдіяльність організму можлива лише при наявності постійного забезпечення органів і тканин кров'ю (Leonova, 1972; Volkov, 1991). Вона постачає необхідні поживні речовини і кисень, а також приймає продукти обміну і діоксид вуглецю, що підлягають видаленню 3 організму через видільні органи (Golikov, 1991; Kondrakhin, 2004). На основі гематологічних даних можна судити про фізіологічний стан тварин, а також прогнозувати його в подальшому. Так, якщо в крові тварин встановлено низьку кількість еритроцитів, лейкоцитів, вмісту гемоглобіну, то такі індивідууми схильні до захворювань (Gorbunova, 2007; Veremey, 2010). Зниження або збільшення кількості еозинофілів $є$ свідченням стресового стану тварин (Daylidenko, 2009; Orbets et al., 2009; Sokolova and Popadyuk, 2010). У спортивних коней гематологічні показники відображають їх функіціональний стан, по ним можно судити про ступінь тренованості і організувати тренінг не допускаючи перевантажень (Kozlov et al., 2008; Petrov, 2011).

Мета роботи $i$ завдання дослідження. Вивчити вплив фізичних навантажень на клініко-фізіологічний стан коней української та тракененської породи.

В завдання досліджень входило : встановити вплив фізичних навантажень на морфологічний профіль коней;

з'ясувати зміни біохімічних показників сироватки крові під впливом тренувань. 


\section{Матеріал і методи досліджень}

В дослідженнях використані спортивні тварини 4 6 річного віку в умовах ВАТ «Орільське» Харківської області. Кров досліджували до і після навантаження, яку брали з периферичних судин. Мазки фарбували за методом Романовського - Гімзе та вели підрахунок формених елементів крові за (Kondrakhin, 2004). Для виконання поставленої мети були використані клінічні гематологічні та біохімічні методи досліджень. Всироватці крові коней визначали та оцінювали: рівень глюкози колориметричним ензиматичним методом 3 набором HTК «LiquievCar-CLycose» фірми CП «Кормей ДиАна - Х»., вміст молочної кислоти - параоксіфіліном піровиноградної кислоти дінітрофенілгідрозіном. Даний набір дозволяє оцінити біохімічні показники організму тварини. Гематологічні дослідження виконували на аналізаторі Medonik CA 620. В стабілізованих пробах крові визначали вміст гемоглобіну, лейкоцитів, еритроцитів, тромбоцитів. Тварин утримували в стайнях 3 вільним входом до левади. Температуру тіла, вимірювали максимальним термометром один раз на добу - ввечері, частоту серцевих скорочень та дихання - шляхом підрахунку за хвилину.

\section{Результати та їх обговорення}

Одним 3 найбільш важливих показників, які характеризують клінічний стан коней є морфологічні дані крові (табл. 1).

Морфологічні показники крові

Табличя 1

\begin{tabular}{|c|c|c|c|c|}
\hline \multirow{3}{*}{ Показник } & \multicolumn{4}{|c|}{ Порода } \\
\hline & \multicolumn{2}{|c|}{ українська верхова } & \multicolumn{2}{|c|}{ тракененська } \\
\hline & до навантаже ння & після наванта ження & до навантаже ння & після наванта ження \\
\hline \multirow{2}{*}{ Еритроцити, Т/л } & $7,3 \pm 0,29$ & $8,26 \pm 0,14$ & $8,25 \pm 0,68$ & $8,37 \pm 0,80^{*}$ \\
\hline & \multicolumn{4}{|c|}{ Норма 9-15,8 } \\
\hline \multirow{2}{*}{ Лейкоцити, Г/л } & $9,17 \pm 1,25$ & $10,12 \pm 1,06$ & $11,30 \pm 1,10$ & $10,12 \pm 1,06$ \\
\hline & \multicolumn{4}{|c|}{ Норма 4-12 } \\
\hline \multirow{2}{*}{ Лімфоцити, г/л } & $4,10 \pm 1,18$ & $4,42 \pm 1,26$ & $3,92 \pm 0,84$ & $3,96 \pm 101,2$ \\
\hline & \multicolumn{4}{|c|}{ Норма 2-9 } \\
\hline \multirow{2}{*}{ Моноцити, г/л } & $0,054 \pm 0,003$ & $0,054 \pm 0,002$ & $0,058 \pm 0,07$ & $0,06 \pm 0,06$ \\
\hline & \multicolumn{4}{|c|}{ Норма -до 0,75} \\
\hline \multirow{2}{*}{ Нейтрофіли, г/л } & $5,94 \pm 1,20$ & $6,12 \pm 1,19 *$ & $7,36 \pm 1,28$ & $7,18 \pm 1,20^{*}$ \\
\hline & \multicolumn{4}{|c|}{ Норма $0,70-7,3$} \\
\hline \multirow{2}{*}{ Гемоглобін, г/л } & $127,3 \pm 20,1$ & $143,2 \pm 3,17^{*}$ & $132,4 \pm 5,09$ & $137,5 \pm 7,4$ \\
\hline & \multicolumn{4}{|c|}{ Норма 90-150 } \\
\hline \multirow{2}{*}{ Тромбоцити г/л } & $107,90 \pm 5,06$ & $128,5 \pm 7,61$ & $120,4 \pm 4,58$ & $127,1 \pm 7,02$ \\
\hline & \multicolumn{4}{|c|}{ Норма 100-800 } \\
\hline
\end{tabular}

Інтенсивна м'язова робота обумовлює зміни морфологічних показників крові у тварин. Так у коней української верхової породи після інтенсивного м'язового навантаження концентрація гемоглобіну становила $143,2 \pm 3,17$ г/л, що вище ніж до тренування на $12,5 \%$, в той же час у тварин тракененської породи цей показник збільшився на $3,8 \%(\mathrm{P}<0,05)$. На наш погляд, це викликано відповідною реаікцією організму на гіпоксію, яка обумовлена підвищеною м'язовою роботою. Можливо коні тракененської породи більш натреновані, а тому коливання за кількістю еритроцитів були незначні $(1,4 \%)$, у індивідуумів УВП - вони становили 13,1\% або 8,26 $\pm 0,14 \mathrm{~T} /$ л $(\mathrm{P}<0,05)$.

Менше реагували на фізичне навантаження за показниками крові коні тракененської породи, що свідчить про відсутність перенавантаження та їх кращу адаптацію до стресових впливів та відповідності виконуючого навантаження клініко - фізіологічного стану. Це підтверджується, на наш погляд, збільшенням кількості тромбоцитів у тракенів до 137,5 \pm 7,4 г/л (на 4,5\%), у УВП - $3107,90 \pm 5,06$ г/л до $128,5 \pm 7,01$ г/л - на $11,9 \%(\mathrm{P}<0,05)$ за рахунок кращої швидкості згортання крові - 10,5 хв, тракененсь- кої породи - 11,03 хв. Про вплив на організм коней фізичного навантаження (до і після тренінгу) судили за біохімічними показниками крові (молочна кислота, резервна лужність, глюкоза). Глюкоза $\epsilon$ основним енергетичним субстратом i за рахунок окислення іiі забезпечується 55\% енергетичних потреб організму.

Відомо, що рівень цукру в крові регулюється ЦНС і особливо її вищим відділом - корою головного мозку, при цьому можливо встановити підвищення цукру в крові - гіперглікемію або його зниження - гіпоглікемію. Наші дослідження (табл. 2) показали, що рівень глюкози у крові коней УВП після посиленого навантаження, знижується до значень $3,92 \pm 0,007$ ммоль/л, або на - 17,2\%, у тракенів - 4,90 $\pm 0,14$ ммоль/л, або на 4,5\% (до 4,09 \pm 0,22 ммоль/л), що свідчить про високі енергетичні потреби тварин УВП $(\mathrm{P}<0,05)$.

Молочна кислота $є$ кінцевим продуктом гліколізу, який утворюється при роботі (тренуваннях). Збільшення вмісту молочної кислоти пов'язане в основному з посиленням іiї утворення в м'язах та пониженням здатності печінки перетворювати молочну кислоту в глюкозу та глікоген. 
Показники біохімічних досліджень крові коней УВП та тракененської породи

\begin{tabular}{|l|c|c|c|c|}
\hline \multirow{2}{*}{ Показники } & \multicolumn{3}{|c|}{ Порода } \\
\cline { 2 - 5 } & \multicolumn{2}{|c|}{ українська верхова } & тракененська \\
\hline & до наванта ження & після наванта ження & до наванта ження & після наванта ження \\
\hline Молочна кислота, мг\% & $6,17 \pm 1,36$ & $6,34 \pm 0,97$ & $5,82 \pm 1,12$ & $6,55 \pm 1,05 *$ \\
\hline Кислотна ємність,мг\% & $580,7 \pm 1,6$ & $630,5 \pm 2,3$ & $590,30 \pm 3,10$ & $510,60 \pm 2,30 *$ \\
\hline Глюкоза, ммоль/л & $4,73 \pm 0,11$ & $3,92 \pm 0,07$ & $4,90 \pm 0,14$ & $4,09 \pm 0,22^{*}$ \\
\hline
\end{tabular}

В наших дослідженнях зниження кислотної ємкості крові у коней тракененської породи до рівня $510,60 \pm 2,30$ мг\% (на 13,6\%) сопроводжувалися підвищенням молочної кислоти на $13,5 \%$ в порівнянні до навантаження, а у тварин УВП на $-2,7 \%$ (Р < 0,05), що узгодждуються 3 даними Е.I. Веремей, 2010 та Г.А. Соколова та спів., 2010.

\section{Висновки}

Коні української верхової та тракененської порід, яким щодня забезпечувався тренінг, адекватно реагували на фізичне навантаження і клініко - фізіологічний стан. Наведені коливання за морфологічним складом та біохімічними показниками знаходяться в межах фізіологічних норм. Більш адаптовані до впливу навантажень коні тракененської та менш - УВП.

Перспективи подальших досліджень. Подальша робота буде спрямована на вивчення імунологічного стану та природної резистентності організму коней.

\section{Бібліографічні посилання}

Veremey, E.I. (2010). Profilaktika zabolevaniy myshts u sportivnykh loshadey. Akt. problemy intensivnogo razvitiya zhivotnovodstva. Gorki. 13, 2, 307-315 (in Russian).

Volkov, D.A. (1991). Ukrainskiye verkhovyye loshadi. Konevodstvo i konnyy sport. 3, 11-13 (in Russian).

Golikov, A.N. (1991). Fiziologiya s.-kh. Zhivotnykh. -3-e izd., pererabot. I dopolnen (in Russian).

Gorbunova, N.D. (2007). Rol' mikroelementov v ratsionakh sportivnikh loshadey. Konevodstvo konniy sport. 1, 31 (in Russian).
Daylidenko, V.I. (2009). Potrebnost' loshadey v biologicheski aktivnykh veshchestvakh [obzor literatury]. Veterinariya s.-kh zhivotnikh. 12, 4-12 (in Russian).

Kozlov, S.A., Zinov'yeva, S.A., Markin, S.S. (2008). Rezul'tativnost' ippodromnykh ispytaniy risistykh loshadey raznikh tipov vysshey nervnoy deyatel'nosti. Selektisionno- tekhnologicheskiye aspekti povisheniya produktivnosti s.-kh v sovremennykh usloviyakh agrarnogo proizvodstva: Mat. mizh. nauch. konf, posvyashchennoy 25-letiyu kafedry chastnoy zootekhniy, tekhnologii proizvodstva i pererabotki produktsii zhivotnovodstva Bryans'ka GSKhA. Bryans'k, 139-142 (in Russian).

Leonova, M.A. (1972). Otsenka stepeni trenirovannosti risistykh loshadey po kompleksu fiziologicheskikh pokazateley. Trenirovka risistykh I verkhovykh loshadey. 26(2), 122-127 (in Russian).

Kondrakhin, I.P. (2004). Metody veterinarnoy klinicheskoy laboratornoy diagnostiki: spravochnik (in Russian).

Orbets, V.A., Orlova, N.E., Sapozhnikov, O.G. (2009). Dinamika gematologicheskikh pokazateley $\mathrm{u}$ konkurnykh loshadey pod deystviyem stressa. Tr. Kubanskogo GAU : seriya Veterinarna nauka. 1(2), 307309 (in Russian).

Petrov, A.V. (2011). Vliyaniye kompleksa mikroelementov na produktivnost $\mathrm{s}$. kh zhivotnykh. Veterinariya i kormleniye. 1, 20-21 (in Russian).

Sokolova, G.A., Popadyuk, S.S. (2010). Kombinasionnaya sposobnost' liniy i simeystv loshadey UVP po kazatelyam robotosposobnosti. Akt. Problem intensivnogo razvitiya / zhivotnovodstva : Sb. nauch. trud. Gorki. 13(2), 110-116 (in Russian).

Стаття надійшла до редакциї 28.03.2017 